\title{
Atrial fibrillation in patients with ischaemic stroke: clinical characteristics and in-hospital outcomes. A pilot study
}

\author{
Migotanie przedsionków u chorych z udarem niedokrwiennym mózgu \\ - charakterystyka kliniczna i rokowanie wewnątrzszpitalne. Badanie pilotażowe ${ }^{* * *}$
}

\author{
Justyna Tracz ${ }^{1}$, Iwona Gorczyca-Michta ${ }^{2}$, Konrad Jarząbek ${ }^{1}$, Ewa Kołodziejska ${ }^{1}$, \\ Anita Rosołowska ${ }^{1}$, Beata Wożakowska-Kapłon ${ }^{2,3}$ \\ ${ }^{1}$ Department of Neurology with Stroke Unit, Świętokrzyskie Neurology Centre, Kielce, Poland \\ ${ }^{2}$ First Department of Cardiology and Cardiac Electrotherapy, Świętokrzyskie Cardiology Centre, Kielce, Poland \\ ${ }^{3}$ Faculty of Medicine and Health, Jan Kochanowski University, Kielce, Poland
}

\section{Abstract}

Introduction. Thromboembolic complications are the most severe consequences of atrial fibrillation (AF). AF is associated with significantly worse outcomes in patients with ischaemic stroke. The aim of the study was to evaluate the prevalence of AF, concomitant conditions, and in-hospital outcomes in patients hospitalized due to ischaemic stroke.

Material and methods. Our retrospective study included 2000 patients hospitalized due to ischaemic stroke in 2013-2014. The diagnosis of ischaemic stroke was based on clinical presentations and brain imaging studies (head CT or MRI).

Results. Overall, AF was present in 579 of 2000 patients (28.5\%) [AF(+) group]. In 456 of these patients (78.8\%), this arrhythmia was diagnosed previously, and in $123(21.2 \%)$ patients AF was newly detected on admission. The mean patient age was 78.6 years in the $\mathrm{AF}(+)$ group and 71.6 years in the $\mathrm{AF}(-)$ group. Carotid ultrasound was performed in 1,805 patients with ischaemic stroke and showed a critical carotid artery stenosis (> 70\%) in 232 patients (16.3\%) in the $\mathrm{AF}(+)$ group and in $69(11.9 \%)$ patients in the $\mathrm{AF}(-)$ group. Major neurological deficit (NIHSS score $>10)$ on admission was found in 485 patients $(34.2 \%)$ in the $\mathrm{AF}(-)$ group and in 196 patients (33.85\%) in the $\mathrm{AF}(+)$ group. At discharge, persistence of a major neurological deficit or worsening of the functional status was noted in 224 patients (15.7\%) without AF and in 226 (39.03\%) patients with AF. Two hundred twenty-nine patients (16.1\%) without AF and 90 patients (15.5\%) with AF died during hospitalization.

Conclusions. Atrial fibrillation was common arrhythmia in patients with ischaemic stroke. Patients with stroke and AF were older than patients with stroke and sinus rhythm. Critical carotid artery stenosis was more common in patients with AF compared to those without AF, as was worsening of the neurological deficit during hospitalization, In-hospital mortality was similar in stroke patients with AF or sinus rhythm.

Key words: ischaemic stroke, atrial fibrillation, thromboembolic complications

Folia Cardiologica 2017; 12, 4: 344-348

\footnotetext{
*Praca powstała w ramach realizacji projektu: „Wzrost konkurencyjności i transfer nowoczesnej technologii poprzez zakup wyposażenia Oddziału Neurologii i Wojewódzkiego Szpitala Zespolonego w Kielcach"

**Praca powstała w ramach projektu „Rola innowacyjnych systemów telemonitorowania w procesie wczesnej rehabilitacji kardiologicznej oraz powrocie chorego do pełnej aktywności fizycznej, psychicznej, społecznej i zawodowej”
}

Address for correspondence: lek. Justyna Tracz, Klinika Neurologii z Pododdziałem Leczenia Udarów Mózgu, Świętokrzyskie Centrum Neurologii w Kielcach, ul. Grunwaldzka 47, 25-736 Kielce, tel. 4136715 96, e-mail: justyna_t@o2.pl 


\section{Introduction}

Atrial fibrillation (AF) is one of the most common arrhythmia and one of the major risk factors for stroke, associated with approximately 5-fold increased stroke incidence [1, 2]. It has been estimated that $20-30 \%$ strokes are due to cardioembolism, mostly caused by AF. The prevalence of $\mathrm{AF}$ increases with age, and $\mathrm{AF}$ becomes an independent risk factor for stroke in subjects above 80 years of age especially [1, 3]. Risk factors for stroke in patients with $\mathrm{AF}$ are included in the $\mathrm{CHA}_{2} \mathrm{DS}_{2}$ VASc risk score: age above 65 years, female gender, hypertension, heart failure, diabetes, vascular disease, and a previous thromboembolic event [4]. Stroke related to AF is characterized by worse clinical course and outcomes, including higher mortality (about $30 \%$ of patients die within 30 days), more disability, and a higher risk of recurrent stroke [3,5-8]. Identification of risk factors and the cause of stroke allows modification of some of these factors and treatment of the underlying conditions.

The aim of the study was to evaluate the prevalence of $A F$ in patients hospitalized due to ischaemic stroke, compare the rates of concomitant conditions in patients with stroke and AF or sinus rhythm, and evaluate in-hospital outcomes in this patient group.

\section{Material and methods}

Our retrospective study included 2000 consecutive patients hospitalized due to ischaemic stroke in a tertiary care neurology centre in 2013-2014. The diagnosis of ischaemic stroke was based on clinical presentations and brain imaging studies (head computed tomography [CT] or magnetic resonance imaging [MRI]).

We analysed data on age, gender, and concomitant conditions such as hypertension, diabetes, lipid abnormalities, and previous thromboembolic event. We evaluate the extent of cerebral infarction based on CT or MRI imaging, and patency of carotid arteries using Doppler ultrasound. Resting electrocardiogram (ECG) was performed in all patients, and Holter monitoring and echocardiography in some patents. Neurological condition of the patients was evaluated using the National Institutes of Health Stroke Scale (NIHSS) on admission and discharge.

\section{Results}

The study included 2000 patients with ischaemic stroke. The mean patient age in the overall study group was 73.6 years, and $49.5 \%$ of patients were women $(n=990)$. Overall, AF was present in 579 of 2000 patients (28.5\%) [AF(+) group]. The $A F(-)$ group included 1421 patients (71.5\%) without history of AF.

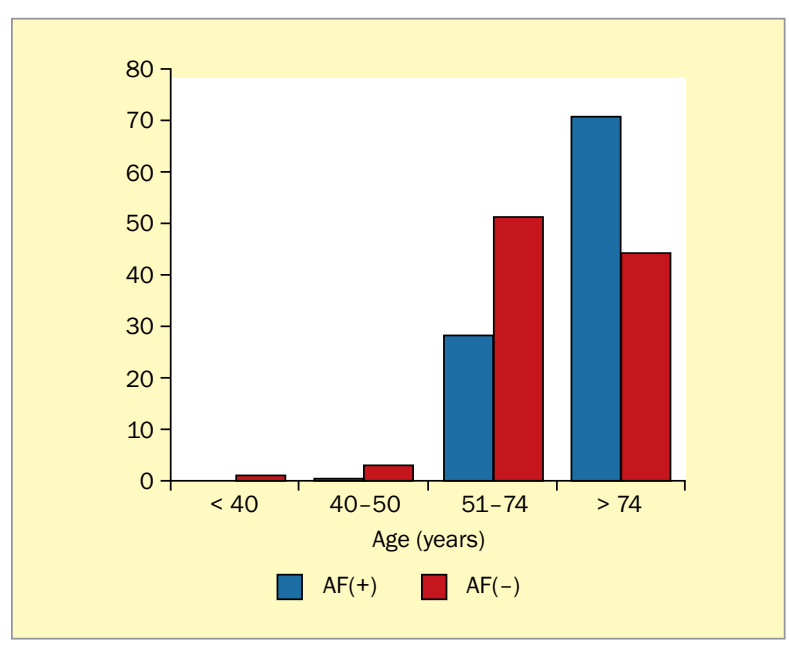

Figure 1. Proportion of patients with ischaemic stroke and atrial fibrillation $[A F(+)]$ versus those with ischaemic stroke and sinus rhythm $[A F(-)]$ in various age groups

Among patients with $\mathrm{AF}$, this arrhythmia was diagnosed before admission in 456 patients (78.8\%), and in $123(21.2 \%)$ patients AF was newly detected on admission. The mean patient age was 78.6 years in the $A F(+)$ group and 71.6 years in the $A F(-)$ group. Overall, the study group $(n=2000)$ included 18 patients $(0.9 \%)$ below 40 years of age, 52 patients (2.6\%) aged $40-50$ years, 893 patients (44.7\%) aged $51-74$ years, and 1037 patients (51.8\%) above 74 years of age. The proportion of patients with and without $A F$ in these age groups was as follows:

- below 40 years of age: 0 vs. 18 patients (1.2\%);

- 40-50 years: 1 patient (0.2\%) vs. 51 patients (3.6\%);

- 51-74 years: 170 patients (29.4\%) vs. 723 patients (50.9\%);

- above 74 years of age: 408 patients $(70.4 \%)$ vs. 629 patients (44.3\%) (Figure 1).

The $\mathrm{AF}(+)$ group included 363 women $(62.7 \%)$ and 216 men (37.3\%). The AF(-) group included 990 women (49.5\%) and 1010 men (50.5\%). Among 579 patients with stroke and $A F$, no risk factors for thromboembolic complications included in the $\mathrm{CHA}_{2} \mathrm{DS}_{2} \mathrm{VASc}$ risk score were found in $28(4.8 \%)$ subjects, compared to 160 subjects (11.2\%) among patients without AF.

Hypertension was the most common risk factor for thromboembolic complications in the overall study group $(n=2,000)$, present in 1,075 subjects $(75.7 \%)$ in the $A F(+)$ group and in 482 subjects (83.3\%) in the $\mathrm{AF}(-)$ group. Heart failure was found in 340 patients $(23.9 \%)$ in the $A F(+)$ group and in 114 patients $(19.7 \%)$ in the $A F(-)$ group. Risk factors for thromboembolic complications in our study group of patients with stroke are shown in Table 1.

A history of thromboembolic event was found in 115 patients (19.9\%) with AF and in 272 patients (19.1\%) without AF. 
Table 1. Risk factors for thromboembolic complications in patients with ischaemic stroke

\begin{tabular}{|c|c|c|c|c|c|c|}
\hline \multirow{2}{*}{$\begin{array}{l}\text { Risk factors for thromboembolic } \\
\text { complications }\end{array}$} & \multicolumn{2}{|c|}{ Overall } & \multicolumn{2}{|c|}{$\mathrm{AF}(+)$} & \multicolumn{2}{|c|}{$\mathrm{AF}(-)$} \\
\hline & $n=2,000$ & $\%$ of patients & $\mathrm{n}=579$ & $\%$ of patients & $n=1,421$ & $\%$ of patients \\
\hline Hypertension & 1557 & 77.9 & 471 & 81.3 & 1086 & 76.4 \\
\hline Diabetes type 2 & 520 & 26 & 159 & 27.5 & 361 & 25.4 \\
\hline Heart failure & 303 & 15.2 & 167 & 28.8 & 136 & 9.6 \\
\hline Female gender & 990 & 49.5 & 358 & 61.8 & 632 & 44.5 \\
\hline Age $65-74$ years & 462 & 23.1 & 115 & 19.9 & 347 & 24.4 \\
\hline Age $>74$ years & 1,035 & 51.8 & 408 & 70.5 & 627 & 44.1 \\
\hline Vascular disease & 1,730 & 86.5 & 484 & 83.6 & 1,246 & 87.7 \\
\hline Previous thromboembolic event & 357 & 17.9 & 115 & 19.9 & 242 & 17 \\
\hline
\end{tabular}

$\mathrm{AF}$ - atrial fibrillation

Carotid ultrasound was performed in 1805 patients with ischaemic stroke. It showed a critical carotid artery stenosis $(>70 \%)$ in 232 patients $(16.3 \%)$ in the $\mathrm{AF}(+)$ group and in 69 (11.9\%) patients in the AF(-) group.

Head CT was performed in all patients during the first day of hospital stay, and repeated brain imaging (CT or MR) was performed during the next 3 days in more than $90 \%$ of patients. Haemorrhagic transformation was seen in 116 patients (5.8\%) in the overall study group, including 29 patients $(5 \%)$ in the $\mathrm{AF}(+)$ group and 87 patients $(6.1 \%)$ in the $\mathrm{AF}(-)$ group. Thrombolytic treatment was administered to 2 patients with haemorrhagic stroke transformation in the $\mathrm{AF}(+)$ group and 25 patients in the $\mathrm{AF}(-)$ group.

Functional status of the patients was evaluated using NIHSS. Major neurological deficit (NIHSS score $>10$ ) on admission was found in 485 patients (34.2\%) in the $\mathrm{AF}(-)$ group and in 196 patients (33.85\%) in the $\mathrm{AF}(+)$ group. At discharge, persistence of a major neurological deficit or worsening of the functional status was noted in 224 patients (15.7\%) without AF and in 226 (39.03\%) patients with AF.

In our study group of patients with ischaemic stroke ( $n=2,000), 229$ patients (16.1\%) without AF and 90 patients $(15.5 \%)$ with AF died during hospitalization.

\section{Discussion}

Atrial fibrillation was common arrhythmia in patients hospitalized for ischaemic stroke (28.9\%). Other authors reported that the prevalence of AF in patients hospitalized for ischaemic stroke was on average 16-26\%. In the Warsaw Stroke Registry in 1991-1992, AF was present in $26 \%$ of patients with stroke [9]. AF increases the risk of stroke 4- to 5 -fold and is the most common risk factor for cardioembolic stroke $[6,8,10]$. Interestingly, in $21 \%$ of patients with AF this arrhythmia was newly found at admission for ischaemic stroke. Staszewski [11] found the same proportion of patients with AF of unknown duration among 838 patients hospitalized due to ischaemic stroke. German Ludwigshafen Stroke Study evaluated 1,231 patients hospitalized due to ischaemic stroke or transient ischaemic attack (TIA). AF was newly detected in $36 \%$ of these patients [12]. In our study, all patients had resting ECG recorded on admission, and most patients underwent Holter monitoring. Stroke may be the initial presentation of AF. Silent AF is associated with a significantly increased risk for thromboembolic complications, mostly due to the fact that patients without symptoms of arrhythmia do not receive anticoagulant treatment which largely reduces the risk of stroke and peripheral embolism.

In our study group, patients with arrhythmia were older than those without arrhythmia. Age is an important factor associated with an increased risk of both AF and ischaemic stroke. In our study, subjects above 74 years of age accounted for a particularly large proportion of patients with AF. Other authors also reported that patients with stroke and $\mathrm{AF}$ were older than those without arrhythmia [11, 12].

In our study group, the proportion of women was higher in those with AF compared to those in sinus rhythm (62\% vs $44 \%$ ). Similarly, in a Swedish registry (Riksstroke) that included 44,173 patients with ischaemic stroke, the proportion of women was higher among subjects with arrhythmia [13]. Female gender is associated with a 1.6-fold increase in the risk of stroke or thromboembolic event. AF is more common in men but the risk of stroke is higher in women $[3,4,14]$.

The most common risk factor for stroke in both patients with $A F$ and those without AF was hypertension, which is in agreement with the reports by other authors [11-13]. Hypertension is associated with 4- to 5-fold increase in the risk of stroke. The risk is further increased with concomitant presence of hypertension and AF. Studies indicated 
that blood pressure reduction by $12 / 5 \mathrm{~mm} \mathrm{Hg}$ reduces the risk of stroke by as much as 30-34\% [14-16]. Appropriate antihypertensive therapy plays a major role in primary and secondary prevention of stroke.

Heart failure was found in $15 \%$ of patients in our study. Among patients with $\mathrm{AF}$, heart failure was more prevalent compared to patients in sinus rhythm. The association between heart failure and $\mathrm{AF}$ is bidirectional in nature. On one hand, heart failure increases the risk of $A F$, and on the other hand, arrhythmia, particularly supraventricular arrhythmia with rapid ventricular response, may result in tachycardia-induced cardiomyopathy.

Previous thromboembolic event (TIA, ischaemic stroke, or systemic embolism) was found in a higher proportion of patients with AF compared to those without AF. A history of a thromboembolic event is associated with an increased risk of a recurrent episode.

In an analysis that included 2,697 patients hospitalized due to ischaemic stroke, a history of stroke was found in $17 \%$ of patients. Multivariate analysis confirmed that in these patients, factors predisposing to recurrent ischaemic stroke include hypertension, AF, and presence of atherosclerotic lesions [17].

Most patients in our study underwent carotid ultrasound to detect atherosclerotic lesions. It showed a critical carotid artery stenosis (> 70\%) in 232 patients $(16.3 \%)$ in the $\mathrm{AF}(+)$ group and in $69(11.9 \%)$ patients in the $\mathrm{AF}(-)$ group. In a study in 899 patients with AF and stroke, significant carotid artery atherosclerotic lesions were found to be associated with an increased risk of recurrent stroke and 30-day mortality [18].

The rates of haemorrhagic complications as documented in follow-up brain CT did not differ significantly between the two groups. However, more patients without AF received thrombolytic treatment which increases the risk of haemorrhagic transformation. Available evidence indicates that cardiogenic embolism, mostly due to AF, increases the risk of haemorrhagic transformation even up to $20-40 \%[8,19]$.

Major neurological deficit on admission was found in similar proportions of patients in the $\mathrm{AF}(+)$ and $\mathrm{AF}(-)$ groups, while worsening of the neurological status was seen more frequently in patients with $\mathrm{AF}$ (39\% vs $15.7 \%)$. Arrhythmia is associated with significantly worse outcomes in patients with stroke. Compared to patients without AF, those with AF are more often found to have early ischaemic changes in brain CT and haemorrhagic transformation in subsequent days, which results in a more severe clinical course of stroke and worse outcomes in these patients [11-13].

In our study, in-hospital mortality was similar in both groups (> 15\%). Other authors reported that 30-day mortality in patients with stroke and AF was $25-30 \%$ compared to $14-17 \%$ in patients with sinus rhythm [11-13]. Lower mortality seen in our study may be related to shorter follow-up, as the duration of hospital stay in our study was 9-20 days.

\section{Conclusions}

1. Atrial fibrillation was common arrhythmia in patients hospitalized due to ischaemic stroke. 2. Patients with stroke and AF were older than patients with stroke and sinus rhythm. 3. In our study group, AF was twice more common in women compared to men. 4. Among patients hospitalized due to ischaemic stroke, critical carotid artery stenosis was more common in patients with AF compared to those without AF. 5. Worsening of the neurological deficit during hospitalization was found more frequently in patients with AF compared to those without AF. 6. In-hospital mortality was similar in stroke patients with AF or sinus rhythm.

\section{Streszczenie}

Wstęp. Powikłania zakrzepowo-zatorowe są najgroźniejszymi konsekwencjami migotania przedsionków (AF). Migotanie przedsionków istotnie pogarsza rokowanie u chorych z udarem niedokrwiennym mózgu. Celem pracy była ocena częstości występowania AF u osób hospitalizowanych z powodu udaru niedokrwiennego mózgu, ocena częstości występowania schorzeń współistniejących oraz ocena rokowania wewnątrzszpitalnego w badanej grupie chorych.

Materiał i metody. Retrospektywnym badaniem objęto 2000 pacjentów z udarem niedokrwiennym mózgu hospitalizowanych w latach 2013-2014. Udar niedokrwienny mózgu rozpoznawano na podstawie obrazu klinicznego pacjenta oraz badań obrazowych głowy (CT lub MRI głowy). 
Wyniki. W całej badanej grupie $(n=2000)$ u 579 chorych $(28,5 \%)$ występowało AF; chorzy ci stanowili grupe AF $(+)$. U 456 badanych (78,8\%) spośród chorych z AF arytmię stwierdzono przed przyjęciem do szpitala, a u 123 (21,2\%) pacjentów AF wykryto po raz pierwszy. Średni wiek pacjentów w grupie $\mathrm{AF}(+)$ wynosił 78,6 roku, a w grupie $\mathrm{AF}(-)$ 71,6 roku. Badanie USG tętnic szyjnych wykonano u 1805 pacjentów z udarem niedokrwiennym mózgu. Badanie to wykazało krytyczne zwężenie naczynia/naczyń (> 70\%) u 232 chorych (16,3\%) w grupie AF(+) i u 69 (11,9\%) chorych w grupie AF(-). Znaczny deficyt neurologiczny (>10 pkt. w NIHSS) przy przyjęciu do szpitala stwierdzono u 485 chorych $(34,2 \%)$ z grupy AF(-) oraz 196 chorych (33,85\%) w grupie AF(+). Przy wypisaniu ze szpitala u 224 badanych (15,7\%) bez AF utrzymywał się znaczny ubytek neurologiczny bądź odnotowano pogorszenie stanu funkcjonalnego, a w grupie AF(+) dotyczył on 226 (39,03\%). W badanej grupie w trakcie hospitalizacji zmarło 229 pacjentów (16,1\%) bez AF oraz 90 badanych (15,5\%) z AF.

Wnioski. Migotanie przedsionków było często stwierdzaną arytmią u chorych z udarem niedokrwiennym. Pacjenci z udarem mózgu i AF byli starsi niż pacjenci z udarem mózgu i rytmem zatokowym. Krytyczne zwężenie tętnic szyjnych stwierdzono u wyższego odsetka chorych z arytmią niż z rytmem zatokowym. Pogorszenie deficytu neurologicznego w trakcie hospitalizacji stwierdzano u wyższego odsetka chorych z AF niż bez arytmii. Śmiertelność wewnątrzszpitalna chorych z udarem mózgu była podobna u chorych z AF i u chorych z rytmem zatokowym.

Słowa kluczowe: udar niedokrwienny, migotanie przedsionków, powikłania zakrzepowo-zatorowe

Folia Cardiologica 2017; 12, 4: 344-348

\section{References}

1. Abu-Assi E, Otero-Raviña F, Allut Vidal G, et al. Grupo Barbanza researchers. Comparison of the reliability and validity of four contemporary risk stratification schemes to predict thromboembolism in non-anticoagulated patients with atrial fibrillation. Int J Cardiol. 2013; 166(1): 205-209, doi: 10.1016/j.jicard.2011.10.096, indexed in Pubmed: 22104995.

2. Banecka-Majkutewicz Z, Nyka W, Krzesniak-Bohdan M, et al. Analiza czynników ryzyka udaru niedokrwiennego mózgu (badanie wstępne). Udar Mózgu. 2002; 4: 15-22.

3. Camm AJ, Kirchhof P, Lip GYH. Guidelines for the management of atrial fibrillation: the Task Force for the Management of Atrial Fibrillation of the European Society of Cardiology (ESC). Europace. 2010; 12(10): 1360-1420, doi: 20876603, indexed in Pubmed: 10.1093/europace/ /euq350.

4. Kirchhof P, Benussi S, Kotecha D, et al. 2016 ESC Guidelines for the management of atrial fibrillation developed in collaboration with EACTS. Eur Heart J. 2016; 37(38): 2893-2962, doi: 10.1093/eurheartj/ehw210, indexed in Pubmed: 27567408.

5. Gladstone DJ, Dorian P, Spring M, et al. EMBRACE Steering Committee and Investigators, EMBRACE Investigators and Coordinators. Atrial fibrillation in patients with cryptogenic stroke. N Engl J Med. 2014; 370(26): 2467-2477, doi: 10.1056/NEJMoa1311376, indexed in Pubmed: 24963566.

6. Hobbs FDR, Fitzmaurice DA, Mant J, et al. A randomised controlled trial and cost-effectiveness study of systematic screening (targeted and total population screening) versus routine practice for the detection of atrial fibrillation in people aged 65 and over. The SAFE study. Health Technol Assess. 2005; 9(40): iii-iv, ix, indexed in Pubmed: 16202350.

7. Lin HJ, Wolf PA, Kelly-Hayes M, et al. Stroke severity in atrial fibrillation: the Framingham Study. Stroke. 1996; 27(10): 1760-1764, doi: 10.1161/01.str.27.10.1760.

8. Jorgensen HS, Nakayama H, Reith J, et al. Acute stroke with atrial fibrillation: the Copenhagen Stroke Study. Stroke. 1996; 27(10): 1765-1769, doi: 10.1161/01.str.27.10.1765.

9. Czlonkowska A, Ryglewicz D, Weissbein T, et al. A prospective community-based study of stroke in Warsaw, Poland. Stroke. 1994; 25(3): 547-551, indexed in Pubmed: 8128505.
10. Pierzchała K, Łabuz-Roszak B, et al. Analiza czynników ryzyka chorób naczyniowych mózgu u chorych leczonych w Pododdziale Udarowym. Wiad Lek. 2006; 63: 1-2.

11. Staszewski J. Atrial fibrillation characteristics in patients with ischaemic stroke. Kardiol Pol. 2007; 65(7): 751-7; discussion 758, indexed in Pubmed: 17694456.

12. Palm F, Urbanek C, Wolf J, et al. Etiology, risk factors and sex differences in ischemic stroke in the Ludwigshafen Stroke Study, a population-based stroke registry. Cerebrovasc Dis. 2012; 33(1): 69-75, doi: 10.1159/000333417, indexed in Pubmed: 22133999.

13. Buchwald F, Norrving Bo, Petersson J. Atrial fibrillation in transient ischemic attack versus ischemic stroke: a Swedish Stroke Register (Riksstroke) Study. Stroke. 2016; 47(10): 2456-2461, doi: 10.1161/ /STROKEAHA.116.013988, indexed in Pubmed: 27561674.

14. Olesen JB, Lip GYH, Lindhardsen J, et al. Risks of thromboembolism and bleeding with thromboprophylaxis in patients with atrial fibrillation: A net clinical benefit analysis using a ,real world' nationwide cohort study. Thromb Haemost. 2011; 106(4): 739-749, doi: 10.1160/ /TH11-05-0364, indexed in Pubmed: 21789337.

15. Maliszewska M. Czynniki ryzyka wystapienia udarów niedokrwiennych mózgu. Przew Lek. 2009; 7: 7-12.

16. Olesen JB, Fauchier L, Lane DA, et al. Risk factors for stroke and thromboembolism in relation to age among patients with atrial fibrillation: the Loire Valley Atrial Fibrillation Project. Chest. 2012; 141(1): $147-$ -153, doi: 10.1378/chest.11-0862, indexed in Pubmed: 21680645.

17. Moerch-Rasmussen A, Nacu A, Waje-Andreassen $U$, et al. Recurrent ischemic stroke is associated with the burden of risk factors. Acta Neurol Scand. 2016; 133(4): 289-294, doi: 10.1111/ane.12457, indexed in Pubmed: 26177064.

18. Lehtola H, Airaksinen KEJ, Hartikainen P, et al. Stroke recurrence in patients with atrial fibrillation: concomitant carotid artery stenosis doubles the risk. Eur J Neurol. 2017; 24(5): 719-725, doi: 10.1111/ /ene.13280, indexed in Pubmed: 28317289.

19. Gurański K, Podemski R, Ejma M. Ukrwotocznione zawały mózgu. Udar Mózgu. 2001; 3: 77-84. 